\title{
Shallow slides and pockmark swarms in the Eivissa Channel, western Mediterranean Sea
}

\author{
G. LASTRAS*, M. CANALS*, R. URGELES*, J. E. HUGHES-CLARKE $\dagger$ and J. ACOSTA $\ddagger$ \\ ${ }^{*}$ GRC Geociències Marines, Universitat de Barcelona, Campus de Pedralbes, Barcelona E-08028, Spain \\ (E-mail: miquel@natura.geo.ub.es) \\ $\dagger$ Ocean Mapping Group, University of New Brunswick, Fredericton, New Brunswick, E3B 5A3, Canada \\ †Instituto Español de Oceanografía, Calle Corazón de María 8, Madrid E-28002, Spain
}

\begin{abstract}
Four slides, the Ana, Joan, Nuna and Jersi slides, have been imaged on the seafloor along the Balearic margin of the Eivissa Channel in the western Mediterranean. They have areas of up to $16 \mathrm{~km}^{2}$ and occur in water depths ranging between 600 and $900 \mathrm{~m}$. Volumes range from $0 \cdot 14$ to $0 \cdot 4 \mathrm{~km}^{3}$. Their headwall scarps, internal architecture and associated deposits are characterized using a combination of swath bathymetry data and very highresolution seismic reflection profiles. In general, they show horseshoe-shaped headwall scarps and distinct depositional lobes with positive relief. Internally, the slide bodies are mostly composed of transparent seismic facies. Chaotic facies are observed at the toe of some of the slides, and blocks of coherent stratified facies embedded in the slide deposit have also been identified. The reflection profiles demonstrate that the four slides share the same slip horizon, which corresponds to a distinctive continuous, high-amplitude reflector. Furthermore, the geometry of the headwall scars of the Nuna and Ana slides reveals evidence of pockmarks, and fluid escape features are also present further upslope. This indicates a possible link between fluid escape features and destabilization of the upper sediment layers. In addition, these wellcharacterized slides demonstrate the pitfalls associated with calculating the volume of the slide masses using headwall scarp heights and the assumed preslide seafloor topography in the absence of seismic data. The internal structure also demonstrates that transport distances within the slides are generally low and poorly characterized by headwall scarp to slide toe lengths.
\end{abstract}

Keywords Eivissa Channel, pockmarks, slides, swath bathymetry, western Mediterranean Sea.

\section{INTRODUCTION}

The advent of swath bathymetry techniques for seafloor mapping and their widespread application has given new insight into how the seafloor is shaped. However, seafloor features with morphological expression that is close to the resolution limits of swath bathymetry and acoustic imaging techniques can be easily overlooked. Fine-scale swath mapping, even at great water depths, is becoming increasingly important for both academia and industry, as illustrated by imaging of the giant Storegga Slide, offshore Norway. Recent work has used a high-resolution multibeam system mounted on an autonomous underwater vehicle to map the seabed above the Ormen Lange gas field area close to the Storegga Slide headwall scarp (Offshore Technology, 2003). The precision of the results contrasts strongly with earlier mapping of the same area (Bugge, 1983). However, underwater vehicles are scarce and expensive and beyond the scope of most swath mapping projects. In addition, they are slow, which means that a lot of time is required to map relatively large areas in the deep sea. Despite its limitations, fine-scale, beam-by-beam processing of swath bathymetry data from surface vessels offers results unachievable by conventional 
processing techniques. Another reasonably cheap alternative is to use surface picks from existing three-dimensional high-resolution seismic reflection data (Bulat, 2003), or high-resolution twodimensional seismic data combined with swath bathymetry when these are available.

One of the areas in which swath bathymetry and high-resolution seismic data have demonstrated their potential during the last decade is the study of mass-wasting events in the deep sea. Mass wasting represents a major geohazard for both offshore infrastructures (Campbell, 1999) and nearby coastal areas (Synloakis et al., 1997). An extensive literature regarding submarine landslides on European and other margins is now available (see compilations in Locat \& Mienert, 2003; Mienert \& Weaver, 2003). A wide range of slide scars and deposits associated with gravitational mass movements has been identified in the western Mediterranean. These include small landslides on the flanks of some of the Balearic Islands (Acosta et al., 2002), the $2000 \mathrm{~km}^{2}$ BIG'95 debris flow on the Ebro slope and base-of-slope (Lastras et al., 2002) and the $60000 \mathrm{~km}^{2}$ Balearic Abyssal Plain megaturbidite described by Rothwell et al. (1998).

In this paper, the character of four small slides in the Eivissa Channel area, between the Iberian Peninsula and the Balearic Islands, is documented (Fig. 1; IEO-IHM, 1999; Acosta et al., 2001a). This study uses a combination of high-resolution swath bathymetry and very high-resolution seismic data to investigate the geometry and internal structure of the slides and to examine the relationship between sliding and gas escape features. The results also have implications for the characterization of less well-imaged submarine slides elsewhere.

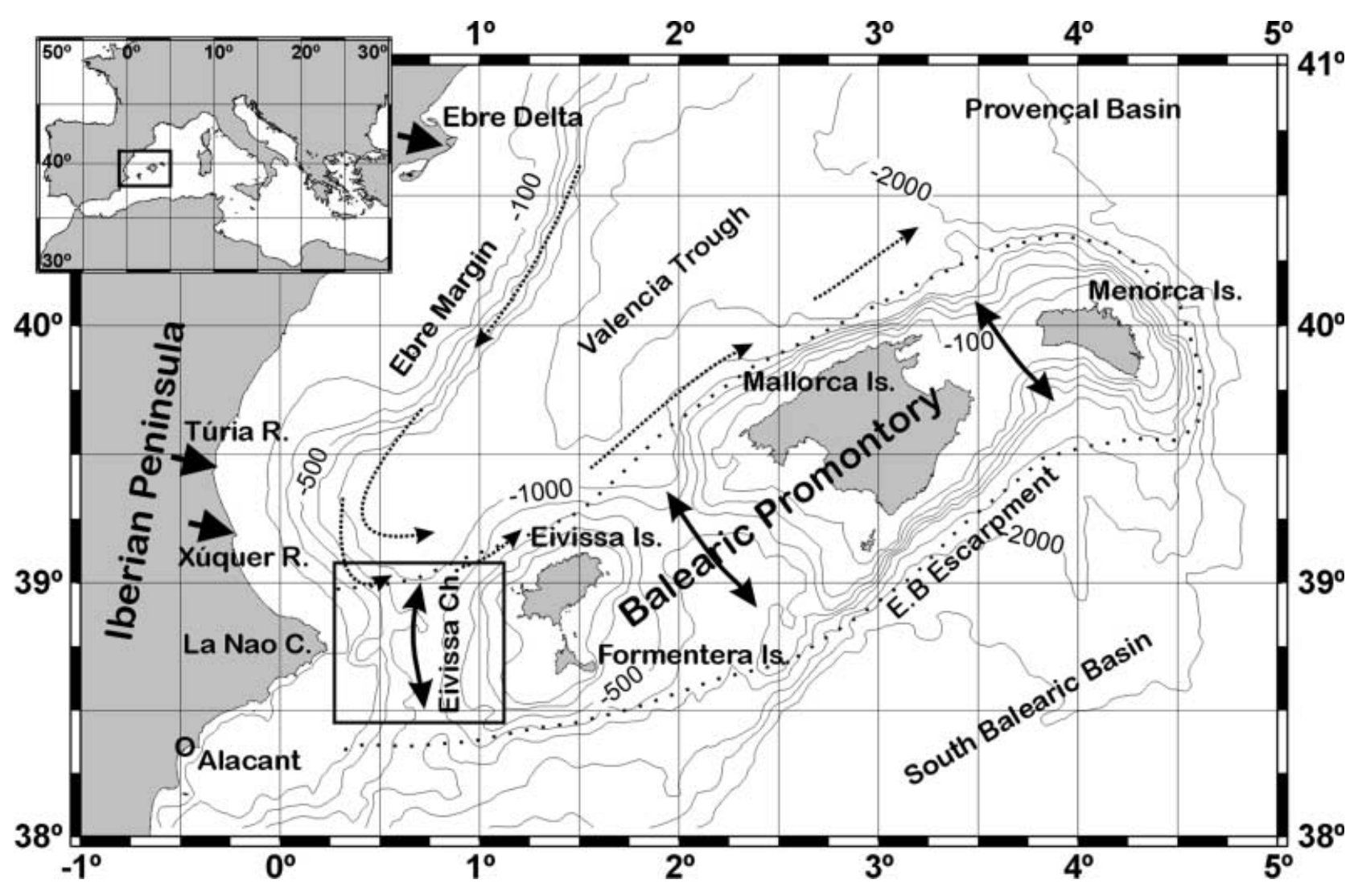

Fig. 1. Bathymetric map of the Balearic Promontory and the surrounding area of the western Mediterranean Sea. Bathymetry data extracted from the Smith \& Sandwell (1997) database. Contours are at 100, 200, 500, 750, 1000, 1500, 2000 and $2500 \mathrm{~m}$. Box shows location of the study area (Fig. 2). The bold arrows mark the areas where interchange of waters between the València Trough and the South Balearic Basin may occur. The dotted arrows show the general direction of currents in the València Trough. The short arrows on the coast mark the location of discharge of the Ebre, Túria and Xúquer (Ebro, Turia and Júcar) rivers. Note that the Eivissa Channel is the deepest channel connecting the València Trough and the South Balearic Basin. 


\section{DATA SET}

The data presented in this paper were collected during two surveys by the $R / V$ Hespérides in 1995 ('BIG'95 survey) and 2002 ('MARINADA' survey), when swath bathymetry data and very high-resolution (VHR) seismic reflection profiles were acquired simultaneously. The EM-12S swath bathymetry $(13 \mathrm{kHz}, 81$ beams $)$ data obtained in 1995, using Simrad's MERLIN/MERMAID acquisition software, were processed using the swathed tools. The results from this processing guided the location of VHR seismic reflection profiles collected during the 2002 cruise. A total of $2287 \mathrm{~km}^{2}$ of bathymetric data were obtained during the two surveys. The seismic reflection system used was a hull-mounted Simrad topographic parametric source TOPAS PS 018, yielding a secondary frequency of $3.5 \mathrm{kHz}$ that allowed $642 \mathrm{~km}$ of good- (1995) to high- (Fig. 2b, 2002) quality profiling. Seismic facies have been described following a simplified Damuth (1980) classification. Positioning of the vessel was ensured by a GPS ASHTECH 3DF system.

\section{STRUCTURAL SETTING}

The Eivissa Channel is situated between La Nao Cape north of the coastal city of Alacant (Alicante) on the Iberian Peninsula, to the west, and the islands of Eivissa (Ibiza) and Formentera, to the east (Fig. 1). It lies at the western end of the $348 \mathrm{~km}$ long and $120 \mathrm{~km}$ wide Balearic Promontory, which includes the Menorca, Mallorca and Eivissa structural blocks, the depressions between them and the Eivissa Channel. The Promontory constitutes the north-eastward prolongation of the external zone of the Betic Ranges from the Iberian Peninsula.

Westward migration of the Alboran microplate to the south along the Emile-Baudot (Fig. 1) and Mazarrón (south-east of the Iberian Peninsula) escarpments (Fontboté et al., 1990; Vegas, 1992; Sàbat et al., 1995; Acosta et al., 2001b) or subduction roll-back of the Alboran arc during the Tertiary (Gueguen et al., 1998) produced a clockwise rotation of the Mallorca and Eivissa blocks. The maximum height of the Balearic Promontory is $\approx 3000 \mathrm{~m}$ above the surrounding seafloor. Neogene volcanic centres are common both on the Balearic Promontory (Acosta et al., 2001b) and in nearby areas (e.g. Maillard \& Mauffret, 1993).

\section{PHYSIOGRAPHY}

Three physiographic elements are distinguished in the Eivissa Channel: (1) the 100-130 m deep continental shelves off Alacant and SW EivissaFormentera; (2) the continental slopes down to $800 \mathrm{~m}$ deep; and (3) a generally smooth median depression that only locally exceeds $900 \mathrm{~m}$ water depth. Overall, the saddle morphology of the north- to south-trending Eivissa Channel is slightly asymmetric, with the Iberian Margin to the west steeper than the Balearic Margin to the east (Fig. 2).

The smoothness of the median depression is interrupted by a prominent $\approx 200 \mathrm{~m}$ high east- to west-trending seamount (Fig. 2), here named the 'Xàbia Seamount' after a nearby coastal town. According to Palomo et al. (1976), this seamount consists of a tilted horst of Cainozoic and possibly older strata. However, unpublished magnetic data suggest a volcanic origin. This latter interpretation is consistent with the presence of other volcanic seamounts in the area around the Eivissa Channel (Maillard \& Mauffret, 1993).

The Xàbia Seamount divides the deep Eivissa Channel into two sectors, the southern sector being double the area of the northern one. The northern Eivissa Channel opens to the north to the València Trough, while the southern sector is connected to the South Balearic Basin across the tectonic escarpments bounding the Balearic Promontory to the south. The maximum water depths in the Eivissa Channel reach $826 \mathrm{~m}$ and $925 \mathrm{~m}$ in the northern and southern sectors, respectively, the latter in an elongated east- to west-oriented depression at the foot of the Xàbia Seamount (Fig. 2).

\section{SEDIMENTATION AND CIRCULATION}

Most of the sediment reaching the Eivissa Channel is thought to come from the Iberian Peninsula. As the regional circulation along the Iberian Margin north of the Eivissa Channel is oriented southward, the channel should receive an influx of fines from rivers to the north such as the Ebre, Túria and Xúquer (Ebro, Turia and Júcar). The Ebre is the largest river in the Mediterranean watershed of the Iberian Peninsula, and the Túria and Xúquer are also among the most important rivers in terms of water and sediment discharge to the València Trough, especially during the intense flood events typical of the Mediterranean climate (Barriendos-Vallvé \& Martín-Vide, 1998). 


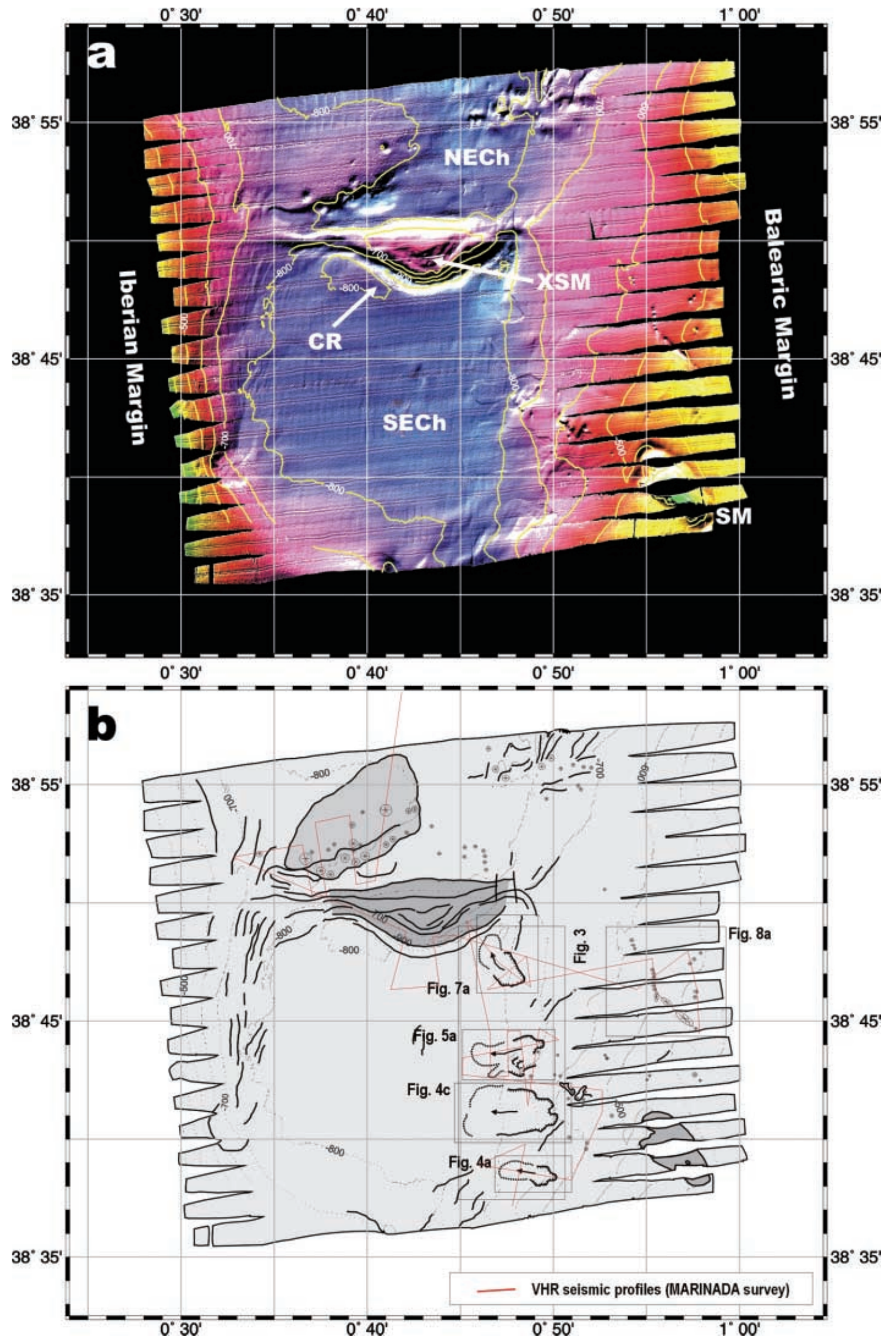

(C) 2004 International Association of Sedimentologists, Sedimentology, 51, 1-14 
Fig. 2. (a) Shaded relief image and swath bathymetry map of the Eivissa Channel, illuminated from the north. Contours are every $100 \mathrm{~m}$. The east- to west-trending Xàbia Seamount (XSM) forms the boundary between the northern (NECh) and southern (SECh) Eivissa Channel. Another seamount is also labelled (SM), as well as the contouritic ridge (CR) south of the Xàbia Seamount. (b) Interpretation of the swath bathymetry map in (a). Dark grey areas represent seamounts while the light grey area corresponds to the pockmark field in the northern Eivissa Channel. Contours every $100 \mathrm{~m}$. Encircled stars show the location of the larger pockmarks. Bold lines represent morphological alignments such as sediment drifts. Boxes show the location of Figs 3, 4a, 4c, 5a, 7a and 8a.

Small mountain rivers with mouths that are located closer to the Eivissa Channel such as the Serpis and Gorgos can also occasionally carry large amounts of sediment during flood events. Despite the likely riverine influence on the Iberian Margin of the Eivissa Channel, patches of benthic carbonate-dominated sedimentation exist on the Balearic continental shelf west of the channel axis according to studies in nearby areas by Canals \& Ballesteros (1996) and Cebrián et al. (2000).

As rainfall is low and the terrain is karstic, no permanent rivers exist on the Balearic Islands. This favours very transparent, oligotrophic waters where sunlight can penetrate to greater depths, thus enhancing the development of carbonateproducing benthic communities on the continental shelf (Canals \& Ballesteros, 1996).

The two sectors in the deep median depression of the Eivissa Channel display contrasting seafloor textures, as seen on swath bathymetry imagery (Fig. 2a), but both sectors are dominated by stratified seismic facies. A rough northern sector, with the seafloor often disrupted by fluid escape features that give it an orange peel texture (Acosta et al., 2001a), contrasts markedly with the essentially smooth-bottomed southern sector. The latter possibly behaves as a sediment trap limited by the Iberian and Eivissa slopes to west and east and the Xàbia Seamount to the north. Its subdued connection with the South Balearic Basin and the dominant current regime (see below) would favour effective sediment trapping in the southern sector.

The Eivissa Channel plays a major role in the exchange of water masses between the South Balearic Basin and the València Trough (Fig. 1). Surface waters with Atlantic influence enter the València Trough through the Eivissa Channel. Northward-directed bottom current velocities range from $23 \mathrm{~cm} \mathrm{~s}^{-1}$ during autumn and winter to less than $5 \mathrm{~cm} \mathrm{~s}^{-1}$ during spring and summer (López-Jurado \& Díaz del Río, 1994). When the flow of water from the south weakens, deep waters originating in the Ligurian Sea and the Gulf of Lions exit the València Trough through the Eivissa Channel. The interaction between near-bottom currents and the seafloor topography associated with the Eivissa Channel has important implications for the sediment dynamics in the area.

The east- to west-oriented depression at the foot of the Xàbia Seamount and the associated parallel sedimentary ridge bounding the depression to the south resemble typical contouritic ridges and associated base-of-slope depressions (Fig. 2; Canals, 1985; Stow et al., 1998; Faugères et al., 1999). The Xàbia Seamount is an obstacle that opposes the northward-moving bottom current. Flow lines concentrate as the bottom current strengthens around the seamount and scours the base of the slope. The eroded material accumulates to the south forming a linked contouritic ridge. No depression or contouritic ridge is observed on the northern side of the Xàbia Seamount, thus demonstrating that the prevailing long-term direction of near-bottom currents is to the north.

\section{MASS WASTING}

After refined processing, the swath bathymetry data obtained in 1995 identified four headwall scars and associated slide deposits roughly aligned along the $0^{\circ} 48^{\prime} \mathrm{E}$ meridian on the Balearic Margin flanking the southern sector of the Eivissa Channel. These occur in water depths ranging between 600 and $900 \mathrm{~m}$ (Figs 2 and 3). The slides, named from south to north, the Ana, Joan, Nuna and Jersi slides, were revisited in 2002 in order to obtain VHR parametric seismic reflection profiles to image their geometry and internal structure in detail. The area of individual slides varies from 6 to $16 \mathrm{~km}^{2}$.

\section{Ana slide}

The Ana slide (Fig. 4a and b) is located between $38^{\circ} 38^{\prime} \mathrm{N}$ and $38^{\circ} 39^{\prime} \mathrm{N}$ and between $0^{\circ} 47^{\prime} \mathrm{E}$ and $0^{\circ} 50^{\prime} \mathrm{E}$, at water depths ranging from $635 \mathrm{~m}$ at the rim of the headwall scar to $815 \mathrm{~m}$ at its toe, with an average slope angle of $1 \cdot 6^{\circ}$. The headwall scarp extends from $635 \mathrm{~m}$ to $740 \mathrm{~m}$ water depth, has a horseshoe shape and is up to $30 \mathrm{~m}$ high. The slide 


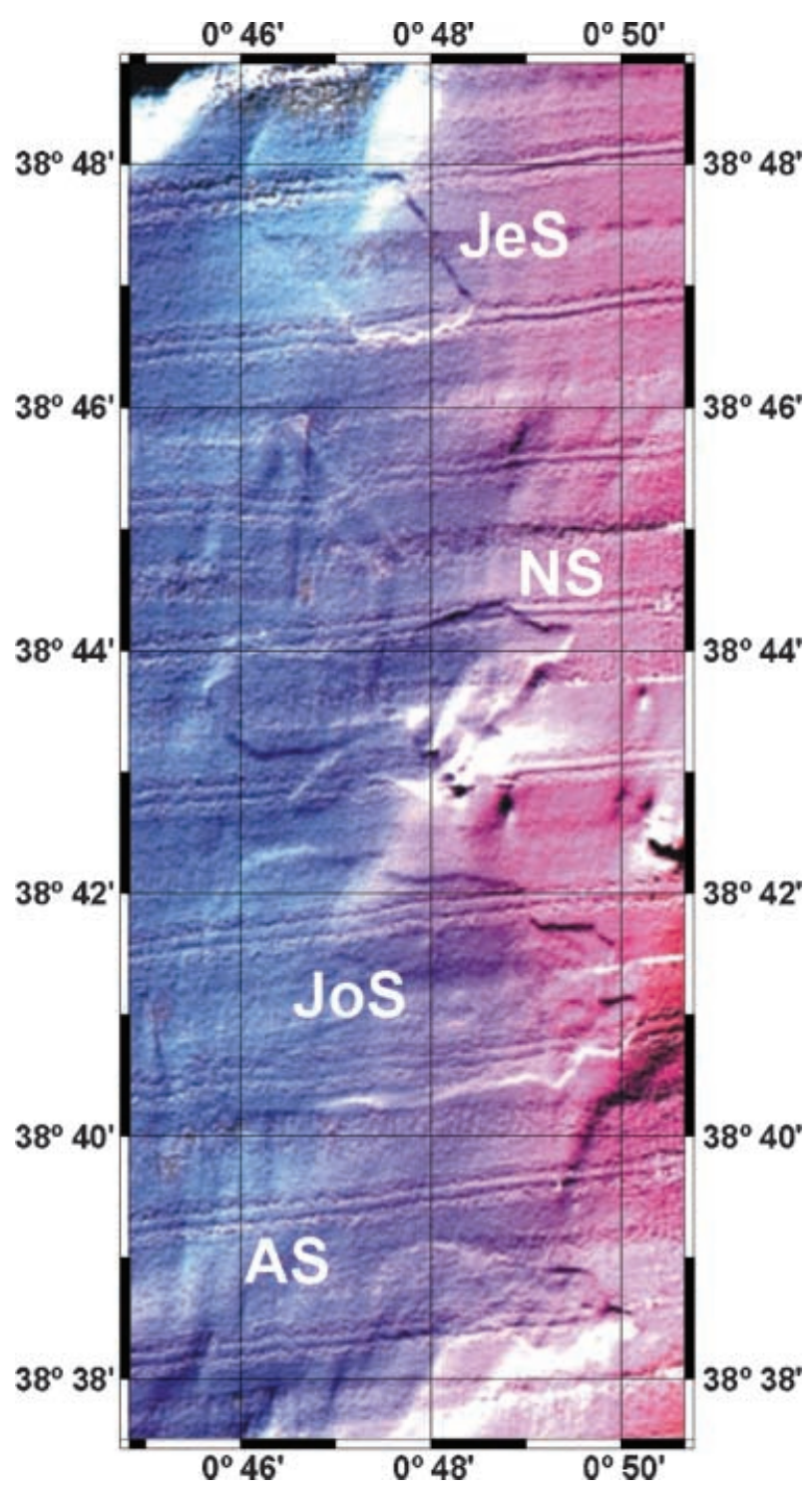

Fig. 3. Shaded relief image of the Eivissa Channel slides, illuminated from the north. From south to north, the slides have been named the Ana slide (AS), Joan slide (JoS), Nuna slide (NS) and Jersi slide (JeS).

has a total length of $4.9 \mathrm{~km}$ and a mean width of $1 \cdot 3 \mathrm{~km}$. It has affected an area of $6 \mathrm{~km}^{2}$ (Fig. 4a).

Seismic reflection profiles along the length of the Ana slide (Fig. 4b) show three seismic facies that succeed one another downslope. At shallower water depths, the slide deposit consists of transparent seismic facies. Slightly rotated, glide blocks with stratified seismic facies can be observed in the central part of the slide. The deposit facies become chaotic at the slide toe, as if in this lower reach there was a lesser degree of sediment disruption compared with the upper part of the slide. Material did not outflow significantly over the slide toe.
The slide deposit has a mean thickness of $23 \mathrm{~m}$ (assuming a velocity of $1500 \mathrm{~m} \mathrm{~s}^{-1}$ for the sediment) and a maximum of $44 \mathrm{~m}$, which is greater than the headwall scarp height. The disturbed sediment thickens downslope towards the distal part of the deposit. Such thickening contrasts with the minimal bathymetric expression of the edge of the depositional lobe in terms of height difference. These observations suggest that modest material transfer is accompanied by the downslope propagation of the deformation front that extensively remoulds the slope sediment without necessarily translating it very far downslope. Most of the sediment in the central and lower slide deposit remains in situ or is only slightly displaced, but it is highly disrupted. Thus, the total length of the slide does not correspond to the runout of sediment. Overall, the total volume of sediment affected is $\approx 0.14 \mathrm{~km}^{3}$.

The slip plane for the Ana slide exploits a characteristic high-amplitude reflector within the seismically well-stratified slope deposits outside the slide. At a short distance from the slide headwall, there is an acoustic wipe-out masking the stratified facies beneath the slide (Fig. 4b). In plan view, this part of the headwall is complicated by a semi-circular embayment (Fig. 4a). Acoustic wipe-out zones can be indicative of the presence of gas in the sediment (O'Leary \& Laine, 1996), and the headwall embayment could mark the location of a former large pockmark (cf. fluid escape features, e.g. Hovland \& Judd, 1988; Acosta et al., 2001a).

\section{Joan slide}

The Joan slide (Fig. 4c) is located approximately between $38^{\circ} 40^{\prime} \mathrm{N}$ and $38^{\circ} 42^{\prime} \mathrm{N}$ and $0^{\circ} 45^{\prime} \mathrm{E}$ and $0^{\circ} 50^{\prime} \mathrm{E}$. It is the largest slide in the region, disturbing $16 \mathrm{~km}^{2}$ of the Eivissa Channel seafloor. The slide occurs between 600 and $\approx 870 \mathrm{~m}$ water depth, and the average slope angle is $2 \cdot 5^{\circ}$. It has a horseshoe-shaped headwall scarp, which is up to $20 \mathrm{~m}$ high, and extends from a water depth of 600 to $820 \mathrm{~m}$ on the basis of multibeam bathymetric mapping (Fig. 4c). The outer limit of the depositional lobe resulting from the Joan slide is poorly defined on swath bathymetry because of its low relief. As no seismic reflection profiles were acquired across the deposit, the thickness has to be inferred from those obtained from the other three slides in the Eivissa Channel (cf. Discussion). The total volume is thus estimated at about $0 \cdot 4 \mathrm{~km}^{3}$ based on an estimated thickness of $25 \mathrm{~m}$. 

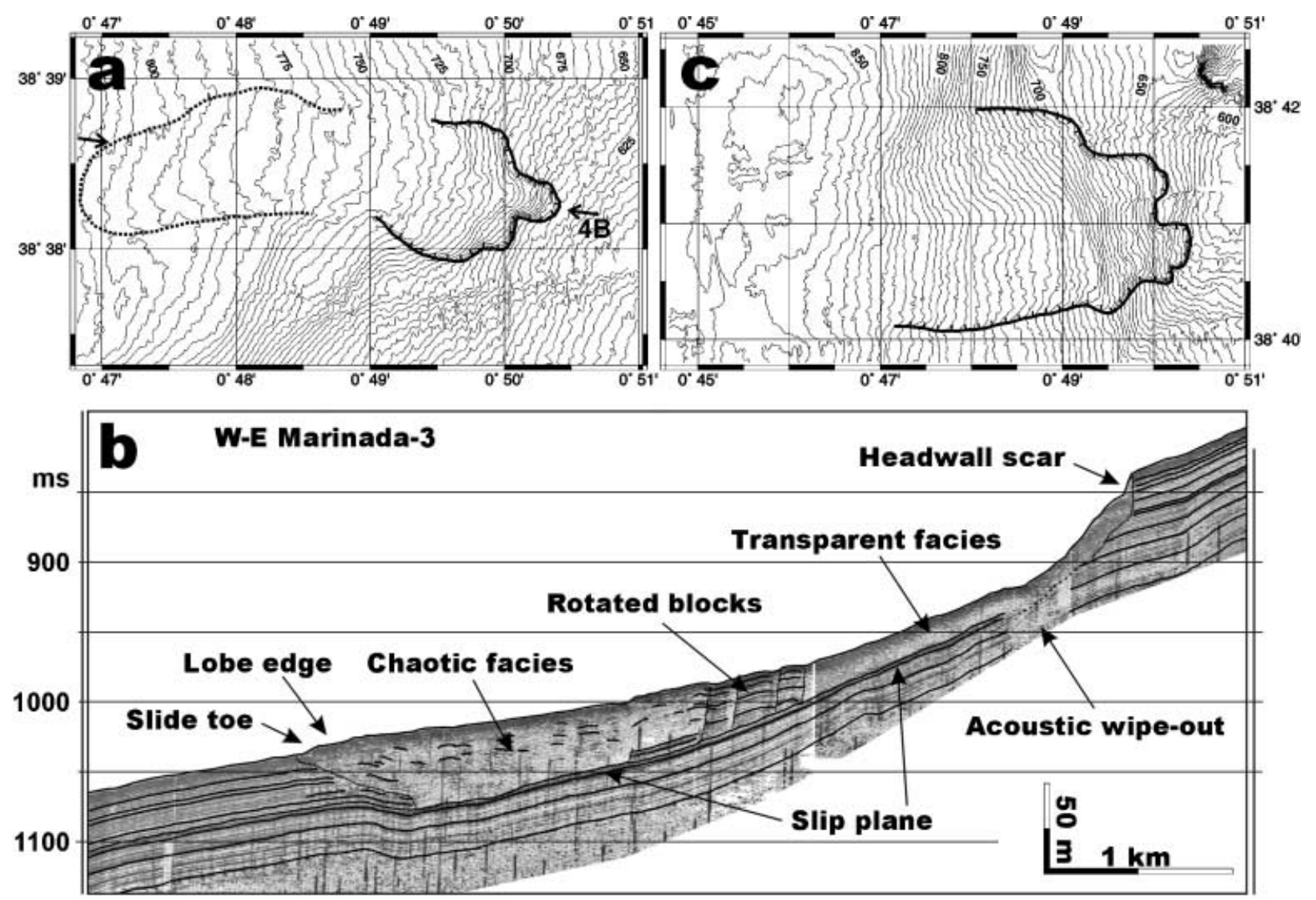

Fig. 4. (a) Swath bathymetry map of the Ana slide. Contours every $5 \mathrm{~m}$. The dotted line outlines the limit of the depositional lobe, and the bold line is the trace of the headwall scarp. Arrows show the location of the profile in (b). (b) Interpreted VHR reflection seismic profile along the Ana slide. Main features within the profile are indicated. See text for explanation. (c) Swath bathymetry map of the Joan slide. Contours every $5 \mathrm{~m}$. The bold line is the headwall scarp. See text for explanation.

\section{Nuna slide}

The Nuna slide complex (Figs 5 and 6) results from two events forming two separate headwalls and lobes to the north and south that are identified on the swath bathymetry imagery and derivative slope maps (Fig. 5a and b) and on VHR seismic reflection profiles (Fig. 5c). The slide complex is located between $38^{\circ} 42^{\prime} 30^{\prime \prime} \mathrm{N}$ and $38^{\circ} 44^{\prime} \mathrm{N}$ and between $0^{\circ} 46^{\prime} \mathrm{E}$ and $0^{\circ} 50^{\prime} \mathrm{E}$ in an area with an average slope angle of $3^{\circ}$. Including the depositional lobes, it affects $10 \cdot 3 \mathrm{~km}^{2}$ of the seafloor at water depths from 675 to $860 \mathrm{~m}$. The headwall scarp has an irregular morphology and ranges from $20 \mathrm{~m}$ high for the northern slide to more than $50 \mathrm{~m}$ high for the southern slide, where steps up to $30 \mathrm{~m}$ high occur (Figs 5a and 6) due to the presence of shallow acoustic basement seen on seismic reflection profiles (Fig. 2b). Swath bathymetry reveals the presence of two pockmarks up to $15 \mathrm{~m}$ deep in the headwall scar area. The $\approx 400 \mathrm{~m}$ in diameter, $<10 \mathrm{~m}$ deep pockmark to the north is almost connected to the northern scar upper rim (Figs 5a and 6).

Seismic reflection profiles across (Fig. 5c) and along (Fig. 6) the Nuna slide complex show the deposit to be made up mainly of transparent seismic facies, but it is also chaotic and discontinuously stratified at its distal most part. It lies on top of the continuously stratified facies that forms the stable Plio-Quaternary sequence. As already seen on the Ana slide, short-distance transport was sufficient to obliterate the internal stratification of the slide mass. Both lobes are characterized by areas of positive and rougher relief with respect to the surrounding undisturbed seafloor (Fig. 5c). The mean thickness of the deposit is $\approx 30 \mathrm{~m}$, rising to a maximum of $50 \mathrm{~m}$ locally. The total volume of disturbed sediment is about $0 \cdot 31 \mathrm{~km}^{3}$. A small, $<5 \mathrm{~m}$ deep, north- to south-oriented, oval-shaped depression observed on top of the deposit at $\approx 810 \mathrm{~m}$ water depth results from the accommodation of the deposit to the topography of the underlying slip 

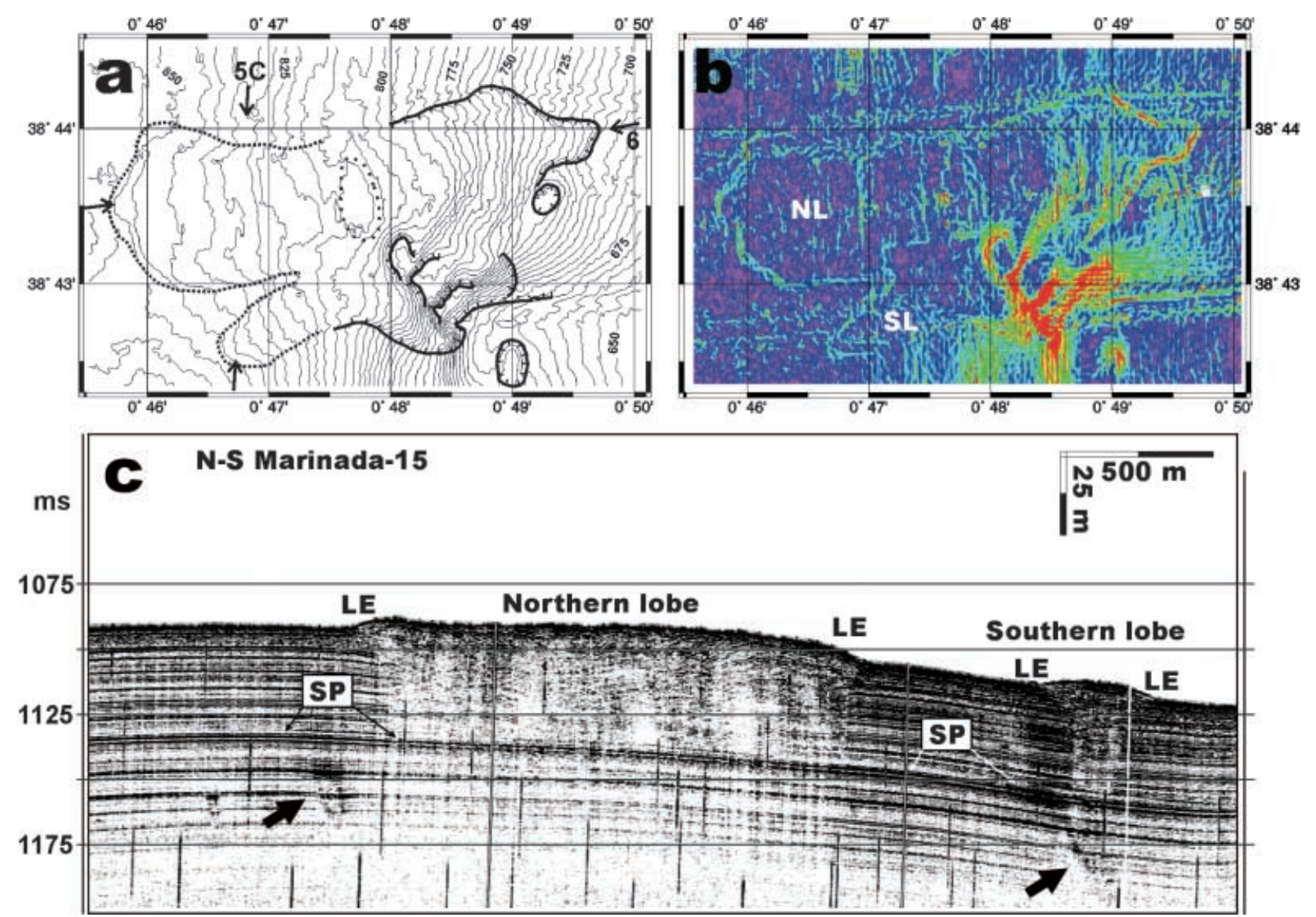

Fig. 5. (a) Swath bathymetry map of the Nuna slide. Contours every $5 \mathrm{~m}$. The dotted line follows the limit of the depositional lobe, and the bold line tracks the headwall scarp. The oval of spaced dots marks a depression within the slide deposit. Arrows show the location of profiles in Figs 5c and 6. (b) Slope gradient map of the Nuna slide. Red, yellow, green and light blue represent high gradients, whereas dark blue and purple represent low gradients. The northern (NL) and southern (SL) lobes are clearly identifiable. See text for explanation. (c) Seismic reflection profile across the toe of the Nuna slide, showing the internal structure and subsurface expression of the two lobes identified, their edges (LE) and the slip plane (SP) of the slide. Black arrows point to 'bright spots' indicative of the presence of gas in the sediment.

plane reflector (Figs 5a and 6). This slip plane reflector displays very high amplitude and continuity and can be identified at the base of both lobes of the Nuna Slide complex. Reflector enhancements or 'bright spots' (black arrows in Fig. 5c), which could relate to the presence of free gas in the sediment, are occasionally observed.

\section{Jersi slide}

The Jersi slide (Fig. 7) is located between $38^{\circ} 46^{\prime} 30^{\prime \prime} \mathrm{N}$ and $38^{\circ} 48^{\prime} 30^{\prime \prime} \mathrm{N}$ and between $0^{\circ} 46^{\prime} \mathrm{E}$ and $0^{\circ} 48^{\prime} 30^{\prime \prime} \mathrm{E}$ in an area with an average slope angle of $1.9^{\circ}$. The Jersi slide has a $15 \mathrm{~m}$ high headwall scarp and affects $7 \cdot 9 \mathrm{~km}^{2}$ of the seafloor in the north-eastern corner of the southern sector of the Eivissa Channel, close to the Xàbia Seamount. Owing to the local topographic influences, the sediment moved north-westwards and not westwards as in the rest of the slides in the area (Fig. 7a).

Seismic reflection profiles along the Jersi slide (Fig. 7b) show that the deposit is characterized by transparent seismic facies. Chaotic seismic facies such as those observed at the toes of the Ana and Nuna slide deposits are not present in this case. Instead, small patches of broken stratified facies can be identified in the upper part of the slide below the headwall step, suggesting that sediment was only slightly disturbed here. The slide deposit overlies the stable stratified Plio-Quaternary sequence of the Eivissa Channel and, as in the other slides, it represents the last sedimentary event in the area. It has a mean thickness of $25 \mathrm{~m}$, giving a total volume of $0 \cdot 19 \mathrm{~km}^{3}$. Seismic reflection profiles also show that the height of the 


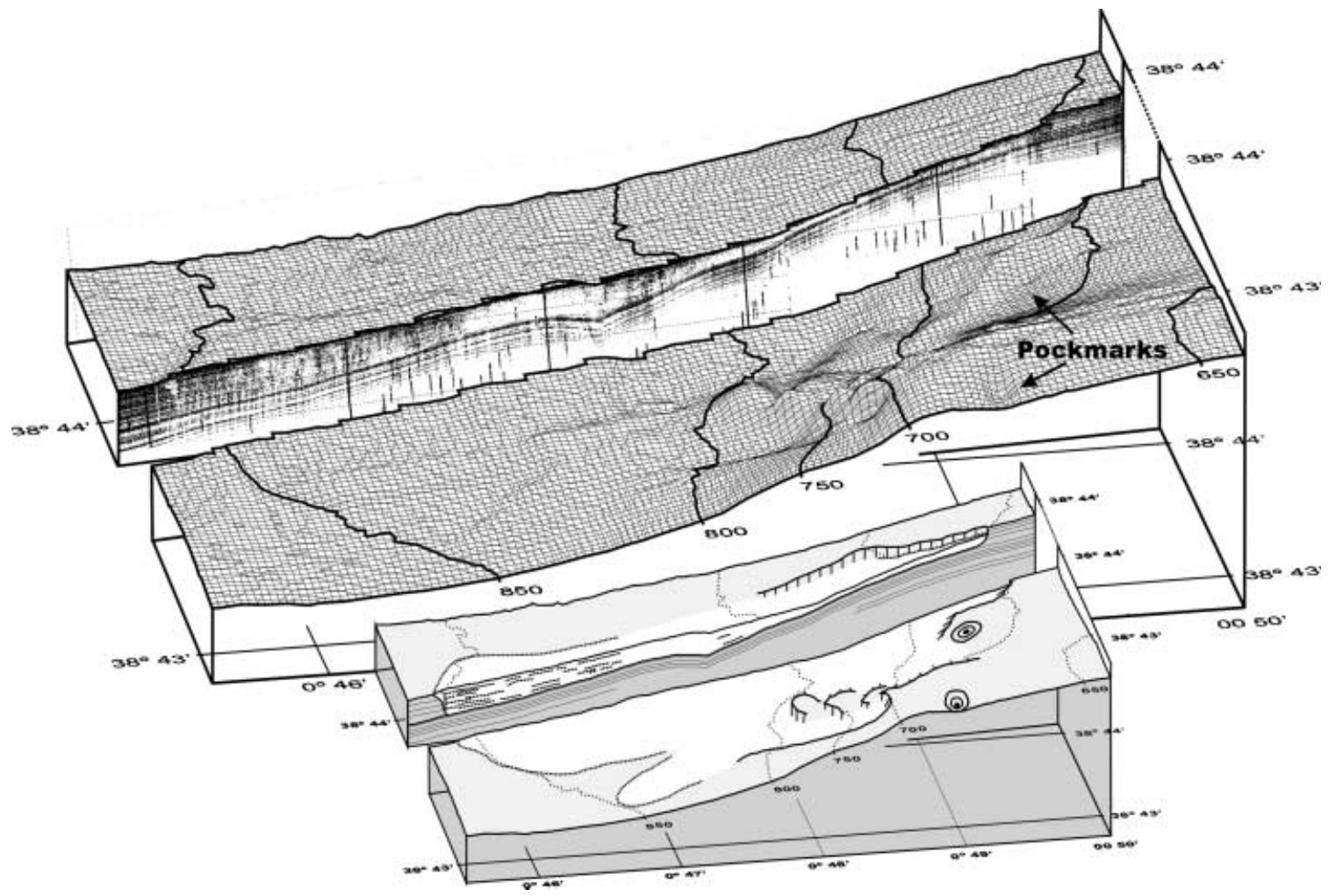

Fig. 6. Bathymetric three-dimensional block model of the Nuna slide area, split along the seismic reflection profile located in Fig. 5a and its interpretation below. Note the different seismic facies within the deposit, as explained in the text, and the presence of two pockmarks close to the headwall scar area.

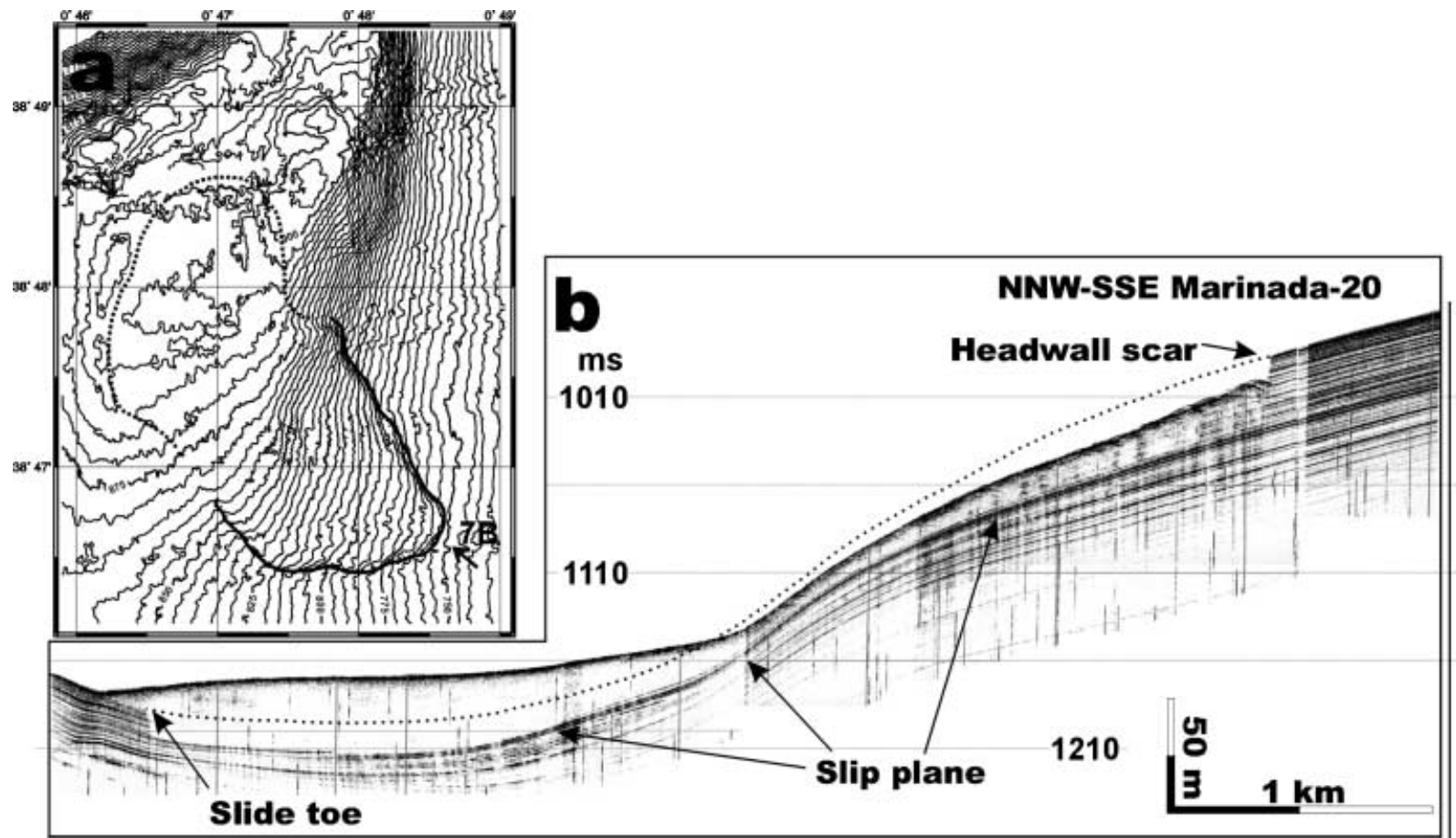

Fig. 7. (a) Swath bathymetry map of the Jersi slide. Contours every $5 \mathrm{~m}$. The dotted line marks the limit of the depositional lobe, and the bold line is the headwall scarp. Arrows show the location of the profile in (b). (b) Seismic reflection profile along the Jersi slide. Main features within the profile are indicated. The dotted line illustrates a tentative reconstruction of the seafloor profile previous to the slide. See text for explanation. 
headwall scarp is not representative of the final thickness of the deposit, as disturbed sediment was not totally evacuated from the headwall scar area. Once again, a prominent high-amplitude reflector forms the slip plane of this slide for which a tentative reconstruction of the seafloor profile before the slide has been made (Fig. 7b).

\section{FLUID ESCAPE FEATURES}

Fluid escape features have been described in the Balearic Promontory by Acosta et al. (2001a), in both the Eivissa Channel and the Mallorca Channel between the islands of Eivissa and Mallorca. These authors relate those features, mostly pockmark fields, to the occurrence of $30 \mathrm{Ma}-$ Recent submarine volcanism as well as to local sagging caused by recent faulting forcing the expulsion of hydrothermal gas and water. They identified the pockmark field north of Xàbia Seamount in the northern Eivissa Channel region (Fig. 2), but finer processing of the swath bathymetry data in this study has allowed the identification of additional pockmark fields and isolated pockmarks in the Balearic Margin south of the Xàbia Seamount (Figs 2b and 8).

In the pockmark field in the northern Eivissa Channel, two families of pockmarks have been identified. The first consists of a group of about 10 large pockmarks up to $500 \mathrm{~m}$ in diameter and up to $50 \mathrm{~m}$ in depth. The second is made of more than 50 small pockmarks with a mean diameter of $10 \mathrm{~m}$ and $<5 \mathrm{~m}$ in depth. Seismic reflection profiles across this pockmark field show that the larger pockmarks are rooted in deep strata beyond the penetration of the seismic system used, while the smaller pockmarks are rooted in a seismic reflector located $\approx 70 \mathrm{~m}$ below the seafloor. Pockmark distribution north of the Xàbia Seamount does not show any clear spatial pattern.

In contrast, pockmarks in the southern Eivissa Channel are often aligned (Fig. 8a). These are rather similar in size, $\approx 100 \mathrm{~m}$ in diameter and $\approx 15 \mathrm{~m}$ in depth, occur at water depths of $\approx 500 \mathrm{~m}$ and are also rooted deeper than the penetration range of the seismic acquisition system (Fig. 8b). The few isolated pockmarks in the southern Eivissa Channel occur at greater water depths and have different sizes. Two of these pockmarks are situated in the vicinity of the headwall scar of the Nuna slide, while a third seems to be related to the headwall scar of the Ana slide. This suggests that fluid escape processes in the upper Plio-Quaternary sedimentary sequence of the Eivissa Channel are closely linked to the observed landslides.

Pockmarks in the Eivissa Channel are either currently active or have been active in recent times. This view is supported by the lack of buried pockmarks in the seismic reflection profiles and by the fact that all of them disturb not only the uppermost sediment layers but also the seafloor. What appear to be active gas-venting plumes have been observed north of the study area by means of a single-beam, high-frequency Simrad EA500 echo sounder during a cruise in
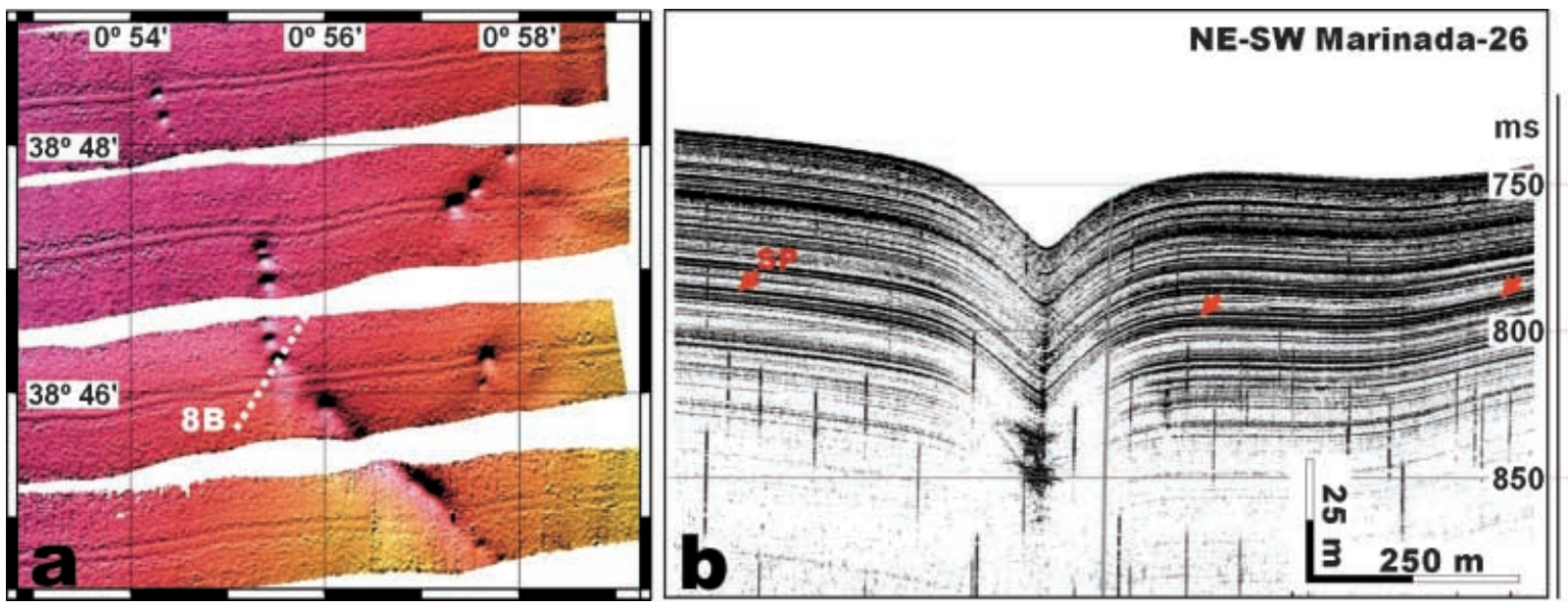

Fig. 8. (a) Shaded relief image of part of the southern Eivissa Channel showing aligned pockmarks, illuminated from the north. The dotted line shows the location of the profile in (b). (b) Seismic reflection profile crossing a large pockmark in the southern Eivissa Channel. Note that the pockmark is rooted below the penetration range of the VHR seismic acquisition system. Red arrows point to the slip plane (SP) of the slides in the Eivissa Channel. 
Fig. 9. Correlation of seismic reflectors underlying the Ana (AS), Nuna (NS) and Jersi (JS) slides. Large arrows (SP) under transparent units (Tr) point to the common slip plane horizon. Correlated reflectors 1-4 are also labelled for ease of comparison.

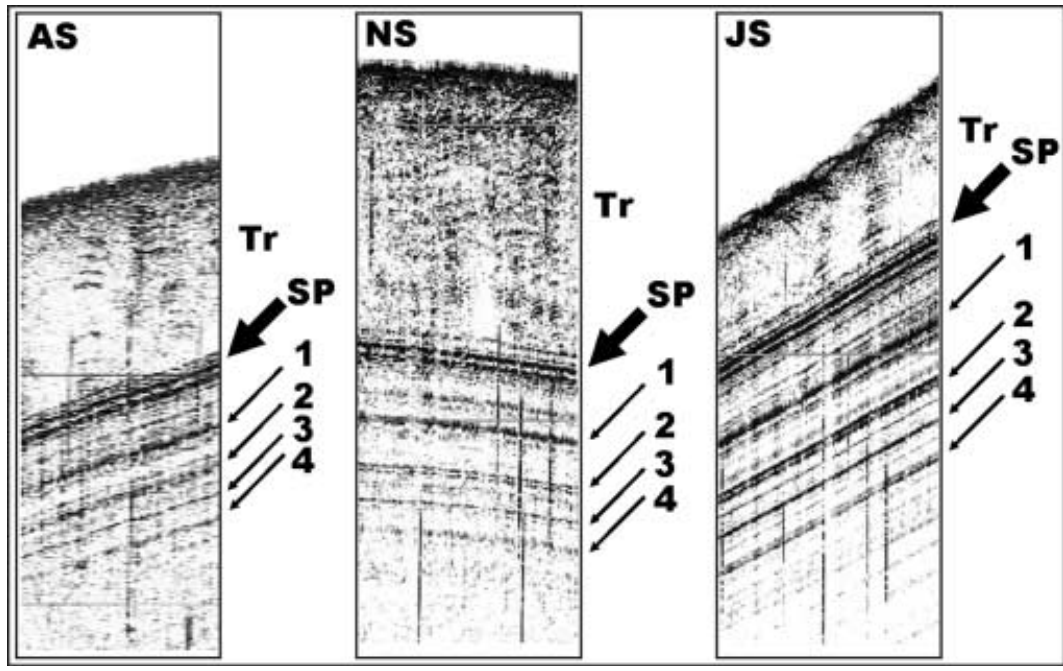

summer 2002 on board the Spanish research vessel Hespérides. The relation of pockmarks and gas hydrates is discarded as the oceanographic setting of this part of the Mediterranean does not allow the presence of gas hydrates (Klauda \& Sandler, 2003). Origin of the fluids has not been studied. These are presumably thermogenic and related to the numerous volcanic structures observed in the Balearic Promontory and its surroundings (e.g. Acosta et al., 2002), although a biogenic contribution cannot be discarded.

\section{DISCUSSION}

Shallow gravity failure of sediment packages may be more likely at certain stratigraphic levels where interstratified layers with contrasting mechanical properties occur. These levels, often identified as weak layers, are strata with sedimentological and geotechnical properties that make them prone to act as slip planes for overlying sediment (e.g. Lykousis et al., 2002). In the case of the four slides studied here, the slip plane can be identified wherever seismic reflection profiles are available, i.e. the Ana, Nuna and Jersi slides. Correlation of seismic reflectors between the various slides reveals that the slip planes for these three slides correspond to the same seismic reflector. A correlation panel of seismic units and reflectors beneath the three slides is plotted in Fig. 9, illustrating how the SP reflector acted as a slip plane in all three cases. This reflector is easily identifiable on most of the seismic profiles (Fig. 2b) and must represent a mechanically weak layer over large areas of the Eivissa Channel.
Such a weakness could be enhanced because of the escape of fluids from the sediment, as indicated by the observation of numerous pockmarks and other fluid-related features such as 'bright spots' seen on the seismic reflection profiles. Pockmarks are frequently observed in regions where mass wasting processes have occurred (e.g. Piper et al., 1999; Hovland et al., 2002). As the pockmarks in the southern Eivissa Channel are rooted below the penetration range of the seismic reflection profiles $(\approx 100 \mathrm{~m})$, the source of the fluids is from below the SP reflector, which is $\approx$ $30 \mathrm{~m}$ below the seafloor in the area of aligned pockmarks (Fig. 8).

The role of pockmarks in triggering the slides may be dual. On the one hand, escaping fluids forming the pockmarks may have been injected into the SP reflector, thus increasing the pore pressure; on the other hand, pockmarks represent a bedding discontinuity presumably reducing the shear resistance along the potential failure plane. These effects would also promote destabilization when combined with maximum slope angles. An indication of this relation is that the Ana, Joan and Nuna slides display curved embayments in the uppermost parts of their headwall scars (Figs 4a and c, 5a and b). These embayments open downslope towards depositional areas. Normally, such geometries may be taken as an indication of retrogressive failure and secondary sliding and degradation of the headwall (Lastras et al., 2003). However, in this case, they could correspond to the remnants of pockmarks that led to the collapse of the upper sediment layers located immediately downslope. Furthermore, the size of the observed uppermost headwall embayments is similar to the size of uncollapsed 
pockmarks seen in the study area, often at a short distance from embayed headwalls (e.g. Nuna slide; Figs 5a and 6). In addition, acoustic wipeout zones that appear below the embayment further support the interpretation of an origin related to fluid escape (e.g. Ana slide; Fig. 4b).

The fact that all the slides in the Eivissa Channel occupy the same stratigraphic position and share the same slip horizon could indicate that they occurred simultaneously following a common triggering mechanism. Significant seismic events have occurred in historic times in nearby areas, e.g. a shock with a local magnitude of 4.8 occurred in Mula, Murcia, in 1999 (URSPA, 2003), and seismogenic faults exist both onshore and offshore capable of generating earthquakes that could induce the failure of sediment piles overlying a weak layer.

An additional lesson arising from the study of the slides in the southern Eivissa Channel relates to the methodology used to calculate the volume of submarine slide and debris flow deposits using the height of the headwall scarp to infer the thickness and, when combined with areal extent, the volume of the final deposit. Such a calculation is normally done in cases when no seismic profiles are available or when they do not penetrate to the base of the disturbed sediment (e.g. McAdoo et al., 2000). This method appears to be inapplicable for the Eivissa Channel slides as the thickness of the deposit is often greater than the height of the headwall scarp (Fig. 7b). Furthermore, the seafloor expression of slide depositional lobes can be subtle when compared with their subsurface expression (Figs $4 b$ and 5c). This implies that the volumes of sediment released from slide scars and transported downslope can be relatively small compared with the volume of mostly in situ sediment disturbed by the passage of materials moving downslope. The sharp lateral change in seismic facies, from chaotic to stratified, below the edge of the depositional lobe of the Nuna slide is a good example of this (Fig. 5c).

Lastly, runout distance is used as one of the key inputs for slide and debris flow modelling. Usually, the total length from the headwall scarp to the slide toe is taken as a measure of runout because of the difficulty in calculating the displacement of the failed sediment mass centre (e.g. McAdoo et al., 2000). The internal character of the Eivissa Channel slides indicates that the headwall-to-toe distance $(\approx 5 \mathrm{~km})$ greatly overestimates the actual transport distance of the remobilized slope sediments caught up in the slides.
The Eivissa Channel slides have yet to be cored. However, the seismic reflection data indicate that the features must be young, as the high-resolution seismic profiling precludes draping of the features by more than $10 \mathrm{~cm}$ of sediment. A coring programme is now needed to date the slide events more precisely and to recover samples of the mechanically weak SP layer on which the sliding occurred.

\section{CONCLUSIONS}

Four small slides have been imaged in the southern Eivissa Channel in the western Mediterranean, at water depths ranging from 600 to $900 \mathrm{~m}$, as a result of fine-scale processing of swath bathymetry data and subsequent acquisition of strategically located VHR seismic reflection profiles. Individual slides are no larger than $16 \mathrm{~km}^{2}$ in area and $0.4 \mathrm{~km}^{3}$ in volume. Their small size allows them to be studied in great detail using seismic reflection profiling, which provides information on the sedimentary architecture of the resulting deposits. A common slip plane for the four slides has been identified and characterized as a layer that extends at least along the whole slope west of Eivissa Island. The presence of fluid escape structures and other features suggesting the occurrence of gas in the sediment combined with the existence of a mechanically weak layer is thought to be the main factor controlling instability in the area. The slides possibly occurred simultaneously and may have been triggered by a seismic event of a magnitude larger than the usual magnitude of 3-4 events in the Eivissa Channel.

In addition, these slides provide a salutary lesson for the study of submarine landslides in the absence of seismic data. Thus, using the height of headwall scars to infer the thickness of the deposits and the total length to infer the actual runout of a remobilized sediment mass may not be appropriate.

\section{ACKNOWLEDGEMENTS}

This study was supported by the V Framework Program Projects COSTA (EVK3-1999-00028) and EUROSTRATAFORM (EVK3-2002-00079) and Research Training Network EURODOM (HPRNCT-2002-00212 from the Human Potential Programme) from the European Community; Projects SPACOMA (01-LEC-EMA14F) and WEST-MED 
(01-LEC-EMA22F) of EUROCORES Program about EUROMARGINS of the European Science Foundation; CYTMAR Project GRANDES (MAR98-0347), a Generalitat de Catalunya Grups de Recerca Consolidats grant (2001 SGR-00076), a Spanish 'Ministerio de Educación, Cultura y Deportes' FPU fellowship (Lastras) and a Spanish 'Ministerio de Ciencia y Tecnología' 'Ramón y Cajal' fellowship (Urgeles). The authors would also like to thank the scientific parties and $R / V$ Hespérides crews who helped to obtain the best data possible during the BIG'95 and MARINADA cruises. The manuscript benefited greatly from thorough comments by reviewers Martin Hovland and Peter Croker, and the editor Peter Haughton.

\section{REFERENCES}

Acosta, J., Muñoz, A., Herranz, P., Palomo, C., Ballesteros, M., Vaquero, M. and Uchupi, E. (2001a) Pockmarks in the Ibiza Channel and western end of the Balearic Promontory (western Mediterranean) revealed by multibeam mapping. Geo-Mar. Lett., 21, 123-130.

Acosta, J., Muñoz, A., Herranz, P., Palomo, C., Ballesteros, M., Vaquero, M. and Uchupi, E. (2001b) Geodynamics of the Emile Baudot Escarpment and the Balearic Promontory, western Mediterranean. Mar. Petrol. Geol., 18, 349-369.

Acosta, J., Canals, M., López-Martínez, J., Muñoz, A., Herranz, P., Urgeles, R., Palomo, C. and Casamor, J.L. (2002) The Balearic Promontory geomorphology (western Mediterranean): morphostructure and active processes. Geomorphology, 49, 177-204.

Barriendos-Vallvé, M. and Martín-Vide, J. (1998) Secular climatic oscillations as indicated by catastrophic floods in the Spanish Mediterranean coastal area (14th-19th centuries). Climatic Change, 38, 473-491.

Bugge, T. (1983) Submarine slides on the Norwegian continental margin, with special emphasis on the Storegga area. Cont. Shelf Inst. Publ., 110, 152 pp.

Bulat, J. (2003) Imaging the Afen slide from commercial 3D seismic - methodology and comparisons with high-resolution data. In: Submarine Mass Movements and Their Consequences (Eds J. Locat and J. Mienert), pp. 205-213. Kluwer Academic Publishers, Dordrecht.

Campbell, K.J. (1999) Deepwater geohazards: how significant are they? Leading Edge, 18, 514-519.

Canals, M. (1985) Estructura sedimentaria y evolución morfológica del talud y el glacis continentales del Golfo de León: Fenómenos de desestabilización de la cobertura pliocuaternaria. PhD Thesis, Universitat de Barcelona, Barcelona (in Spanish).

Canals, M. and Ballesteros, E. (1996) Production of carbonate particles by phytobenthic communities on the Mallorca -Menorca Shelf, northwestern Mediterranean Sea. Deep-Sea Res., 44, 611-629.

Cebrián, E., Ballesteros, E. and Canals, M. (2000) Shallow rocky bottom benthic assemblages as calcium carbonate producers in the Alboran Sea (southwestern Mediterranean). Oceanol. Acta, 23, 311-322.
Damuth, J.E. (1980) Use of high-frequency (3.5-12 kHz) echograms in the study of near-bottom sedimentation processes in the deep-sea: a review. Mar. Geol., 38, 51-75.

Faugères, J.C., Stow, D.A.V., Imbert, P. and Viana, A. (1999) Seismic features diagnostic of contourite drifts. Mar. Geol., 162, 1-38.

Fontboté, J.M., Guimerà, J., Roca, E., Sàbat, F., Santanach, P. and Fernández-Ortigosa, F. (1990) The Cenozoic geodynamic evolution of the València Trough (western Mediterranean). Rev. Soc. Geol. Esp., 3, 249-259.

Gueguen, E., Doglioni, C. and Fernández, M. (1998) On the post 25-Ma geodynamic evolution of the western Mediterranean. Tectonophysics, 298, 259-269.

Hovland, M. and Judd, A.G. (1988) Seabed Pockmarks and Seepages. Impact on Geology, Biology and the Marine Environment. Graham and Trotman, London, $293 \mathrm{pp}$.

Hovland, M., Gardner, J.V. and Judd, A.G. (2002) The significance of pockmarks to understanding fluid flow processes and geohazards. Geofluids, 2, 127-136.

IEO-IHM (1999) Zona Económica Exclusiva, Hoja M-13. Mapa Batimétrico. Ministerio Agricultura, Pesca y Alimentación, Instituto Español de Oceanografía, Departamento de Geología y Geofísica Marina, Madrid.

Klauda, J.B. and Sandler, S.I. (2003) Predictions of gas hydrate phase equilibria and amounts in natural sediment porous media. Mar. Petrol. Geol., 20, 459-470.

Lastras, G., Canals, M., Hughes-Clarke, J.E., Moreno, A., De Batist, M., Masson, D.G. and Cochonat, P. (2002) Seafloor imagery from the BIG'95 debris flow, western Mediterranean. Geology, 30, 871-874.

Lastras, G., Canals, M. and Urgeles, R. (2003) Lessons from sea-floor and subsea-floor imagery of the BIG'95 debris flow scar and deposit. In: Submarine Mass Movements and Their Consequences (Eds J. Locat and J. Mienert), pp. 425-431. Kluwer Academic Publishers, Dordrecht.

Locat, J. and Mienert, J. (eds) (2003) Submarine Mass Movements and Their Consequences. Kluwer Academic Publishers, Dordrecht, $552 \mathrm{pp}$.

López-Jurado, J.L. and Díaz del Río, G. (1994) Dinámica asociada a las masas de agua en el Canal de Ibiza en noviembre de 1990 y marzo de 1991. Bol. Inst. Esp. Oceanogr., 10, $3-22$.

Lykousis, V., Roussakis, G., Alexandri, M., Pavlakis, P. and Papoulia, P. (2002) Sliding and regional slope stability in active margins: North Aegean Trough (Mediterranean). Mar. Geol., 186, 281-298.

McAdoo, B.G., Pratson, L.F. and Orange, D.L. (2000) Submarine landslide geomorphology, US continental slope. Mar. Geol., 169, 103-136.

Maillard, A. and Mauffret, A. (1993) Structure et volcanisme de la Fosse de Valence (Méditerranée nord-occidentale). Bull. Soc. Géol. France, 164, 365-383.

Mienert, J. and Weaver, P.P.E. (eds) (2003) European Margins Sediment Dynamics: Side-Scan Sonar and Seismic Images. Springer-Verlag, Heidelberg, $310 \mathrm{pp}$.

O'Leary, D.W. and Laine, E. (1996) Proposed criteria for recognizing intrastratal deformation features in marine high resolution seismic reflection profiles. Geo-Mar. Lett., 16, 305-312.

Offshore Technology (2003) Offshore Technology - gas field project - Ormen Lange - North Sea, Northern Norway. [WWW document] URL: http://www.offshore-technology.com/projects/ormen/.

Palomo, C., Acosta, J., de Andrés, J., Herranz, P., Rey, J. and Sanz, J.L. (1976) Perfiles geofísicos entre la península y las 
Islas Baleares. $2^{\mathrm{a}}$ Asamblea Nacional de Geodesia y Geofísica, 13-17 December 1976, Madrid. Comunicaciones, III, 1615-1627.

Piper, D.J.W., Cochonat, P. and Morrison, M.L. (1999) The sequence of events around the epicentre of the 1929 Grand Banks earthquake: initiation of debris flow and turbidity current inferred from sidescan sonar. Sedimentology, 46, 79-97.

Rothwell, R.G., Thomson, J. and Kähler, G. (1998) Low sealevel emplacement of a very large late Pleistocene 'megaturbidite' in the western Mediterranean Sea. Nature, 392, 377-380.

Sàbat, F., Roca, E., Muñoz, J.A., Vergés, J., Santanach, P., Sans, M., Masana, E., Estévez, A. and Santisteban, C. (1995) Role of extension and compression in the evolution of the eastern margin of Iberia: the ESCI-Valencia Trough seismic profile. Rev. Soc. Geol. Esp., 8, 431-448.
Smith, W.H.F. and Sandwell, D.T. (1997) Global seafloor topography from satellite altimetry and ship depth soundings. Science, 277, 1957-1962.

Stow, D.A.V., Faugères, J.C., Viana, A. and Gonthier, E. (1998) Fossil contourites: a critical review. Sed. Geol., 115, 3-31.

Synloakis, C.E., Liu, P., Carrier, G. and Yeh, H. (1997) Tsunamigenic sea-floor deformation. Science, 278, 598-600.

URSPA (Unidad de Registro Sísmico de la Provincia de Alicante) (2003) Unidad de Registro Sismológico. [WWW document] URL: http://www.ua.es/ursua/.

Vegas, R. (1992) The Valencia Trough and the origin of the western Mediterranean basins. Tectonophysics, 203, 249-261.

Manuscript received 1 May 2003; revision accepted 25 March 2004. 